\title{
LEVEL OF KNOWLEDGE OF PHYSICAL EDUCATION PROFESSIONALS ABOUT AEROBIC AND RESISTANCE EXERCISE PRESCRIPTION FOR ELDERLY PEOPLE
}

\section{CONOCIMIENTO DE LOS PROFESIONALES DEEDUCACIÓN FÍSICA SOBRE PRESCRIPCIÓN DEL EJERCICIO AERÓBICO Y RESISTIDO PARA INDIVIDUOS DE LA TERCERAEDAD}

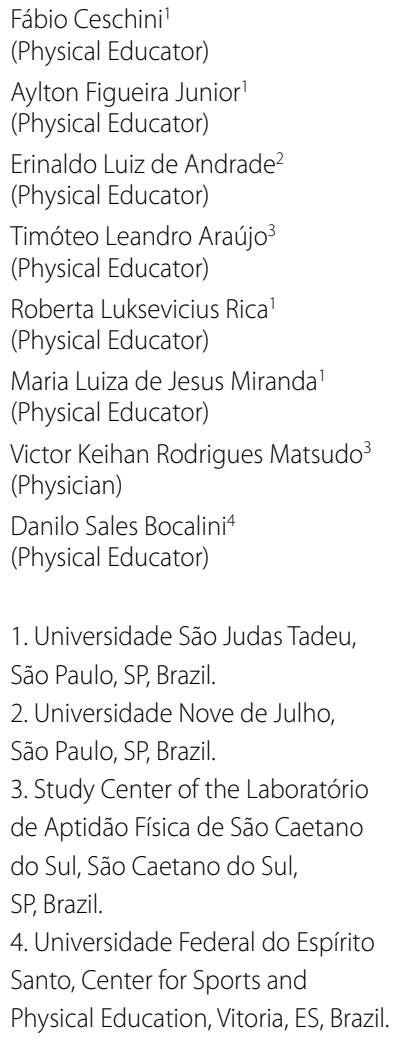

\section{Correspondence:}

Danilo Sales Bocalini.

Rua Militão Barbosa de Lima, 132, Centro, São Bernardo do Campo, São Paulo, Brazil. 09720-420. bocaliniht@hotmail.com

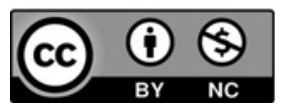

\begin{abstract}
Introduction: Regular aerobic and resistance exercises are recommended to improve functional capacity and quality of life in the elderly. Objective: To describe the familiarity of physical education professionals with the recommendation of aerobic and resistance exercise for the elderly, and to identify associated factors. Methods: We assessed 610 physical education professionals working in fitness academies in the city of São Paulo. Familiarity with the recommendation was assessed using a questionnaire constructed for this study. We assessed the criteria that make up the recommendation of aerobic and resistance exercise, following the American College of Sports Medicine guidelines. The data analysis with statistical significance of $p<0.05$ was carried out using the chi-square test and multiple logistic regression. Results: The level of knowledge of physical education professionals working in fitness centers, considering fulfilment of the criteria that make up the recommendation of aerobic and resistance exercise for the elderly, was limited, attaining only $9.3 \%$ and $12.6 \%$, respectively. Age, number of jobs, completion of a graduate program and reading of scientific papers were factors associated with familiarity with the recommendation of resistance exercise. Factors associated with familiarity with aerobic exercise recommendation were: age, number of jobs and reading of scientific papers. Conclusion: The level of familiarity of physical education professionals with the recommendation of aerobic and resistance exercise for older people was low, suggesting the need for better professional training to meet the demand of older people at the fitness centers in the city of Sao Paulo. Level of Evidence l; Type of Study: Therapeutic Study - Investigation of Treatment Results.
\end{abstract}

Keywords: Aerobic exercise; Resistance training; Knowledge; Guidelines as Topic.

\section{RESUMO}

Introdução: A prática regular de exercícios aeróbicos e resistidos é recomendada para a melhora da capacidade funcional e da qualidade de vida de idosos. Objetivo: Descrever o conhecimento dos profissionais de Educação Física sobre a recomendação do exercício aeróbico e resistido para idosos e identificar os fatores associados. Métodos: Foram avaliados 610 profissionais de Educação Física atuantes em academias de ginástica de São Paulo. O conhecimento da recomendação foi avaliado por meio de um questionário construído para este estudo. Foram avaliados os critérios que compõem a recomendação do exercício aeróbico e resistido, seguindo as diretrizes do Colégio Americano de Medicina do Esporte. A análise dos dados com significância estatística de $p<0,05$ foi realizada pelo teste do qui quadrado e pela regressão logística múltipla. Resultados: O conhecimento dos profissionais de Educação Física atuantes em academias, considerando todos os acertos dos critérios que compõem a recomendação do exercício aeróbico e resistido para idosos, foi baixo, sendo apenas 9,3\% e 12,6\%, respectivamente. Idade, quantidade de empregos, ter curso de pós-graduação finalizado e leitura de artigos científicos foram fatores associados ao conhecimento da recomendação do exercício resistido. Os fatores associados ao conhecimento da recomendação do exercício aeróbico foram idade, quantidade de empregos e leitura de artigos científicos. Conclusão: O conhecimento dos profissionais de Educação Física com relação à recomendação do exercício aeróbico e resistido para idosos foi baixo, sugerindo a necessidade de melhor capacitação profissional para atender a demanda de idosos nas academias de São Paulo. Nível de Evidência l; Tipo de Estudo: Terapêutico - Investigação dos Resultados do Tratamento

Descritores: Exercício aeróbico; Treinamento de resistência; Conhecimento; Diretrizes.

\section{RESUMEN}

Introducción: La práctica regular de ejercicios aeróbicos y resistidos es recomendada para la mejora de la capacidad funcional y calidad de vida de personas de la tercera edad. Objetivo: Describir el conocimiento de los profesionales de Educación Física sobre la recomendación del ejercicio aeróbico y resistido para personas de la tercera edad e identificar los factores asociados. Métodos: Fueron evaluados 610 profesionales de Educación Física actuantes en gimnasios de São Paulo. El conocimiento de la recomendación fue evaluado por medio de un cuestionario construido para este 
estudio. Fueron evaluados los criterios que componen la recomendación del ejercicio aeróbico y resistido, siguiendo las directrices del Colegio Americano de Medicina del Deporte. El análisis de los datos con significancia estadística de $p<0,05$ fue realizado por el test del qui cuadrado y por la regresión logística múltiple. Resultados: El conocimiento de los profesionales de Educación Física actuantes en gimnasios, considerando todos los aciertos de los criterios que componen la recomendación del ejercicio aeróbico y resistido para personas de la tercera edad fue bajo, siendo sólo 9,3\% y 12,6\%, respectivamente. La edad, cantidad de empleos, tener curso de postgrado finalizado y lectura de artículos científicos fueron factores asociados al conocimiento de la recomendación del ejercicio resistido. Los factores asociados al conocimiento de la recomendación del ejercicio aeróbico fueron edad, cantidad de empleos y lectura de artículos científicos. Conclusión: El conocimiento de los profesionales de Educación Física con relación a la recomendación del ejercicio aeróbico y resistido para personas de la tercera edad fue bajo, sugiriendo la necesidad de una mejor capacitación profesional para atender la demanda de personas mayores en los gimnasios de São Paulo.

Nivel de Evidencia l; Tipo de Estudio: Terapéutico - Investigación de los Resultados del Tratamiento.

Descriptores: Ejercicio aeróbico; Entrenamiento de resistencia; Conocimiento; Directrices.

\section{INTRODUCTION}

The combination of harmful habits and advancing age is critical to the development of non-transmissible chronic diseases (NTCD) such as diabetes, cancer, obesity, and cardiovascular diseases. Therefore, people $>60$ years of age are considered a potential risk group that deserves the attention of public health authorities ${ }^{1-4}$.

Several morphofunctional changes are observed during the aging process, such as reduced muscle mass and consequent decreased strength, endurance, and muscle strength; and reduced bone mass, equilibrium, memory capacity, and cardiorespiratory capacity resulting in lower functional capacity and decreased activities of daily living ${ }^{3-5}$.

Scientific evidence suggests that the regular practice of physical activity is the most effective means of minimizing the negative effects of aging on physical fitness since it improves functional indicators in the elderly and improves NTCD control ${ }^{3-7}$. Global institutions such as the World Health Organization ${ }^{6}$ and the American College of Sports Medicine ${ }^{3}$ officially recommend that older people practice daily aerobic exercise and resistance training with the aim of improving health and functional capacity.

The prescription and monitoring of exercise programs must be performed by professionals trained in physical education practices with different population groups to offer exercise guidance, monitoring, and prescriptions for educational purposes, prevent and control chronic diseases, promote health, and improve physical performance ${ }^{7-8}$.

Nevertheless, studies have shown insufficient knowledge of physical education professionals in relation to the variables of exercise prescriptions for some groups, such as diabetics ${ }^{9-10}$ and hypertensive patients ${ }^{11}$, and no studies have examined elderly populations. Therefore, the objective of this study was to describe the knowledge of the criteria of physical education professionals working in gyms regarding the prescription of aerobic and resistance exercise for elderly populations according to the American College of Sports Medicine and associated factors.

\section{METHODS}

This study is part of a more comprehensive project that aimed to elucidate the knowledge of physically trained professionals working in gyms on the recommendation of aerobic and resistance exercise for healthy adults, elderly and people with a diagnosis of NTCD, based on the recommendations of the American College of Sports Medicine. ${ }^{3}$

The following parameters were considered in the sample size estimate: a) $60 \%$ prevalence of correct answers of all criteria for the recommendation of aerobic and resistance exercise; 2) sampling error of 3 percentage points; and 3) 95\% confidence interval (CI). Thus, the minimum required sample was 422 physical education professionals.

A total of 610 physical education professionals of both sexes aged 22-57 years (mean, 33.7 years; standard deviation, 10.2 years) in gyms in São Paulo were evaluated. The study was performed after a random survey of 74 gyms in São Paulo to achieve the minimum number required in the sample considering all the geographical regions of the city of São Paulo (Center, South, North, East, and West).

After the gym selection, the professionals were selected at random and stratified according to the following inclusion criteria: 1) registration in the Regional Council of Physical Education [Conselho Regional de Educação Física - (REF-SP]; 2) bachelor's degree in physical education; and 3) performing any type of exercise in the selected gyms. The professionals who worked in more than one of the included gyms selected for the study were excluded from the sample.

The data collection was performed using a questionnaire designed and built specifically for this study containing 60 closed questions to obtain information about demographic, socioeconomic, and behavioral indicators as well as knowledge of the criteria of the American College of Sports Medicine for prescribing aerobic and resistance exercises to the elderly ${ }^{3}$.

Each question in the questionnaire presented 5 closed response options for each criterion of the recommendation of aerobic and resistance exercise with only one being the correct answer. The following criteria were considered suitable for aerobic exercise in the elderly: 1) Weekly frequency: 5 times a week; 2) Duration: 30 minutes per session; 3) Intensity: moderate controlled by a Subjective Effort Perception scale ranging from 0 to 10 points, where 5-6 points indicate moderate intensity and 7-8 indicates vigorous intensity. For the recommendation of resistance exercise, the following criteria were considered: 1) Weekly frequency: at least 2 times a week; 2) Number of exercises: 8-10 for large muscle groups; 3) Number of series: between 1 and 3; 4) Number of repetitions: from 8 to 12 .

For organizational purposes, the results are described in tables considering each criterion of the prescription of aerobic and resistance exercise in an isolated manner (Aerobic Exercises: only the weekly frequency, duration or intensity; Resistance Exercises: only the weekly frequency, number of series, number of repetitions, and number of exercises) and considering the set of all criteria of the recommendation of aerobic exercise and resistance (only those professionals who answered all criteria of the recommendation).

The gym visits occurred between August and November 2014. Physical education professionals who participated in the sample answered the questionnaire anonymously without any interference from the research team. To validate the questionnaire, a pilot study was conducted with 
50 randomly selected volunteers to evaluate the comprehension of the issues, relationship between question and answer, and reproducibility of the instrument after approval was received from the Research Ethics Committee of São Judas Tadeu University (No. 100\2011).

Descriptive statistics was used to count the frequency of responses and the calculation of proportions. Cronbach's alpha coefficient was used to test the instrument's internal consistency. The Chi-square test for linear trend and heterogeneity was applied to associate the knowledge of all criteria of the recommendation of aerobic exercise and resistance in accordance with the independent variables. A multivariate analysis was performed by logistic regression to estimate the odds ratio (OR) and respective $95 \% \mathrm{Cl}$ with the order of entry of the variables according to the hierarchical model of causality determined a priori ${ }^{12}$.

The hierarchical model included three levels of importance of the dependent variables; for the independent variable to remain in the adjusted model, it should present a significance of $p<0.20$ in the crude analysis. In the first level, the demographic indicators (sex and age) were entered; in the second level, the economic indicators (time of coursework completion, having finalized graduate coursework, time of completion of postgraduate coursework, number of jobs, and gym size); and in the third level, the behavioral indicators (weekly hours spent reading, type of reading). The significance level adopted was $p<0.05$.

\section{RESULTS}

The analysis of the internal consistency of the research instrument presented high values ( 0.79 in women, 0.73 in men). Table 1 shows the positive answers for prescription of aerobic exercise. The highest percentage of hits was for criteria duration (71.5\%), weekly frequency (60.3\%), and intensity (20.2\%). Only 9.3\% of the professionals met all of the criteria. For resistance exercise, the highest success rate was for weekly frequency (45.2\%), number of repetitions (41.8\%), number of exercises (26.2\%), and number of sets (23.9\%). Knowledge was only $12.3 \%$.

The knowledge of the criteria duration and weekly frequency for prescriptions of aerobic exercise for elderly individuals were significantly associated with the following variables: age, completion of graduate coursework, time to completion of postgraduate courses, number of jobs, and type of reading. The intensity criterion was associated with the following variables: age, having completed graduate coursework, number of jobs, and type of reading (Table 2).

A significant association was observed between the highest percentage of knowledge with age range, number of jobs that the physical education professional had, and type of reading. For all other independent variables, there were no significant associations. In the regression model, the adjusted model maintained a similar behavior of the variables compared to the crude model (Table 3).

Professionals who reported reading only scientific articles showed a 2.3-fold greater chance of meeting all the criteria of the recommendations than those who have the habit of reading both books and scientific articles (OR, 2.30; 95\% Cl, 1.11-5.61).

Tables 4 and 5 present the findings regarding the criteria that comprise the prescription of resistance exercises. The weekly frequency criterion was associated with knowledge of the following variables: age range, postgraduate coursework completed, gym size, number of jobs, and type of reading. The knowledge of the criterion number of exercises was associated with the end time of undergraduate coursework, having finished postgraduate coursework, the end of the postgraduate coursework, gym size, and type of reading. The knowledge of the criterion number of series was associated with age range, having finished postgraduate coursework, end time of postgraduate coursework, gym size, and type of reading. The knowledge of the criterion number of repetitions was
Table 1. Sample distribution by independent variable.

\begin{tabular}{|c|c|c|}
\hline Independent variables & $\mathrm{N}$ & $\%$ \\
\hline \multicolumn{3}{|l|}{ Sex } \\
\hline Male & 271 & 44,4 \\
\hline Female & 339 & 55,6 \\
\hline \multicolumn{3}{|l|}{ Age range, years } \\
\hline $22-29$ & 187 & 30,7 \\
\hline $30-39$ & 126 & 20,7 \\
\hline $40-49$ & 174 & 28,5 \\
\hline$\geq 50$ & 123 & 20,2 \\
\hline \multicolumn{3}{|c|}{ Time of completion of graduate coursework, years } \\
\hline$\leq 1$ & 86 & 14,1 \\
\hline $1-3$ & 197 & 32,3 \\
\hline $4-6$ & 222 & 36,4 \\
\hline$\geq 7$ & 105 & 17,2 \\
\hline \multicolumn{3}{|l|}{ Completed graduate coursework } \\
\hline Yes & 340 & 55,7 \\
\hline No & 270 & 44,3 \\
\hline \multicolumn{3}{|l|}{$\begin{array}{l}\text { Time to completion of postgraduate } \\
\text { coursework, years }\end{array}$} \\
\hline$\leq 1$ & 43 & 12,6 \\
\hline $1-2$ & 138 & 40,6 \\
\hline $3-5$ & 120 & 35,3 \\
\hline$\geq 6$ & 39 & 11,5 \\
\hline \multicolumn{3}{|l|}{ Gym size } \\
\hline Small (up to 499 students) & 144 & 23,6 \\
\hline Average (500-999 students) & 199 & 32,6 \\
\hline Large ( $\geq 1000$ students) & 267 & 43,8 \\
\hline \multicolumn{3}{|l|}{ Number of jobs } \\
\hline 1 & 360 & 59,0 \\
\hline 2 & 168 & 27,5 \\
\hline 3 & 82 & 13,4 \\
\hline \multicolumn{3}{|l|}{ Hours of weekly reading } \\
\hline$\leq 1$ & 220 & 36,1 \\
\hline $1-2$ & 234 & 38,4 \\
\hline$\geq 3$ & 156 & 25,6 \\
\hline \multicolumn{3}{|l|}{ Type of reading } \\
\hline Books and scientific articles & 192 & 31,5 \\
\hline Only scientific articles & 260 & 42,6 \\
\hline Websites and non-scientific text & 158 & 25,9 \\
\hline \multicolumn{3}{|l|}{ Recommendation of aerobic exercise } \\
\hline Weekly frequency & 368 & 60,3 \\
\hline Session length (minutes) & 436 & 71,5 \\
\hline Relative intensity & 123 & 20,2 \\
\hline All hits & 57 & 9,3 \\
\hline \multicolumn{3}{|c|}{ Recommendation of resistance exercise } \\
\hline Weekly frequency & 276 & 45,2 \\
\hline Number of exercises & 160 & 26,2 \\
\hline Number of series & 146 & 23,9 \\
\hline Number of repetitions & 255 & 41,8 \\
\hline All hits & 77 & 12,6 \\
\hline Total & 610 & 100,0 \\
\hline
\end{tabular}

associated with the end time of the postgraduate coursework, gym size, and number of jobs.

The results presented in Table 5 show the percentage of hits taking "all the hits" of the criteria of the prescription of exercise for elderly people and the crude and adjusted logistic regression model. Knowledge of all correct answers was associated with the following independent variables: time of the completion of undergraduate coursework, graduate coursework completed, time of completion of the postgraduate coursework, and type of reading.

In the regression model, the adjusted model maintained similar behavior of the variables compared to that of the crude model. Professionals who reported reading books and scientific articles were 2.23-fold more likely to correctly answer all of the criteria of the prescription of exercise for the elderly population than professionals who did not have a habit of reading books and scientific articles $(\mathrm{OR}, 2.23 ; 95 \% \mathrm{Cl}, 1.04-4.75 ; \mathrm{p}<0.001$ - adjusted model), while those who reported reading mainly scientific articles were almost three-fold more likely to meet all of the criteria of the prescription ( $\mathrm{OR}, 2.87 ; 95 \% \mathrm{Cl}, 1.41-5.87 ; \mathrm{p}<0.001$ - adjusted model). 
Table 2. Description of the knowledge of the physical education professionals by independent variable according to criteria of the recommendation of the prescription of aerobic exercise for elderly people.

\begin{tabular}{|c|c|c|c|}
\hline \multirow[b]{2}{*}{ Independent variable } & \multicolumn{3}{|c|}{$\begin{array}{c}\text { Aerobic exercise } \\
\text { Prescription variables }\end{array}$} \\
\hline & $\begin{array}{c}\text { Weekly } \\
\text { frequency } \\
\mathrm{N}(\%)\end{array}$ & $\begin{array}{c}\text { Duration } \\
\text { of session } \\
\mathrm{N}(\%)\end{array}$ & $\begin{array}{c}\text { Relative } \\
\text { intensity } \\
\mathrm{N}(\%)\end{array}$ \\
\hline Sex & NS & NS & NS \\
\hline Male & $164(44,6)$ & $192(44,0)$ & $56(45,5)$ \\
\hline Female & $204(55,4)$ & $244(56,0)$ & $67(54,5)$ \\
\hline Age range, years & * & $* *$ & $*$ \\
\hline $22-29$ & $110(29,9)$ & $146(33,5)$ & $33(26,8)$ \\
\hline $30-39$ & $76(20,7)$ & $88(20,2)$ & $22(17,9)$ \\
\hline $40-49$ & $94(25,5)$ & $106(24,3)$ & $31(25,2)$ \\
\hline$\geq 50$ & $88(23,9)$ & $96(22,0)$ & $37(30,1)$ \\
\hline $\begin{array}{l}\text { Time of completion of } \\
\text { graduate coursework, years }\end{array}$ & NS & NS & NS \\
\hline$\leq 1$ & $52(14,1)$ & $63(14,4)$ & $18(14,6)$ \\
\hline $1-3$ & $115(31,3)$ & $145(33,3)$ & $44(35,8)$ \\
\hline $4-6$ & $138(37,5)$ & $159(36,5)$ & $45(36,6)$ \\
\hline$\geq 7$ & $63(17,1)$ & $69(15,8)$ & $16(13,0)$ \\
\hline Completed graduate coursework & * & * & * \\
\hline Yes & $216(58,7)$ & $244(56,0)$ & $70(56,9)$ \\
\hline No & $152(41,3)$ & $192(44,0)$ & $53(43,1)$ \\
\hline $\begin{array}{c}\text { Time to end of postgraduate } \\
\text { coursework, years }\end{array}$ & * & * & NS \\
\hline$\leq 1$ & $27(12,5)$ & $28(11,5)$ & $14(20,0)$ \\
\hline $1-2$ & $88(40,8)$ & $107(43,8)$ & $25(35,7)$ \\
\hline $3-5$ & $78(36,1)$ & $87(35,7)$ & $24(34,3)$ \\
\hline$\geq 6$ & $23(10,6)$ & $22(9,0)$ & $7(10,0)$ \\
\hline Gym size & NS & NS & NS \\
\hline Small ( $\leq 499$ students) & $80(21,7)$ & $101(23,2)$ & $35(28,5)$ \\
\hline Average (500-999 students) & $116(31,5)$ & $152(34,8)$ & $35(28,5)$ \\
\hline Large ( $\geq 1000$ students) & $172(46,8)$ & $183(42,0)$ & $53(43,0)$ \\
\hline Number of jobs & * & * & * \\
\hline 1 & $224(60,9)$ & $260(59,6)$ & $78(63,4)$ \\
\hline 2 & $91(24,7)$ & $112(25,7)$ & $34(27,7)$ \\
\hline 3 & $53(14,4)$ & $64(14,7)$ & $11(8,9)$ \\
\hline Hours of weekly reading & NS & NS & NS \\
\hline$\leq 1$ & $135(36,7)$ & $162(37,2)$ & $45(36,6)$ \\
\hline $1-2$ & $137(37,2)$ & $156(35,7)$ & $49(39,8)$ \\
\hline$\geq 3$ & $96(26,1)$ & $118(27,1)$ & $29(23,6)$ \\
\hline Type of reading & * & $*$ & * \\
\hline Books and scientific articles & $108(29,3)$ & $134(30,7)$ & $33(26,8)$ \\
\hline Only scientific articles & $158(43,0)$ & $187(42,9)$ & $55(44,7)$ \\
\hline Websites and non-scientific texts & $102(27,7)$ & $115(26,4)$ & $35(28,5)$ \\
\hline Total & $368(100,0)$ & $436(100,0)$ & $123(100,0)$ \\
\hline
\end{tabular}

NS, not significant; ${ }^{*} p<0.05 ;{ }^{* *} p<0.001$

\section{DISCUSSION}

Exercise is essential for functional improvement and disease risk reduction in the elderly ${ }^{13-16}$. A longitudinal study showed that women with high levels of daily physical activity had a lower risk of mortality due to cardiovascular diseases and cancer ${ }^{17}$. Thus, the correct prescription of aerobic and resistance exercise according to official recommendations is a determining factor in terms of functional benefits, autonomy, and health promotion for the elderly 18,19,20,21.

This was the first study to evaluate the knowledge of physical education professionals working in gyms in relation to the recommendation of aerobic and resistance exercises in the elderly. The results of this study showed that the knowledge of each criterion of the prescription, both aerobic and resistance exercise, analyzed in isolation was higher in relation to the knowledge considering all criteria. These results deserve attention given the increase in the number of elderly people who adhere to exercise programs at gyms, which may indicate low-quality guidance, planning, and provision of service.

This deficiency can be related to the less discussion on this topic in undergraduate courses. This would indicate a probable gap in knowledge
Table 3. Regression model of the knowledge of physical education professionals by independent variable given the correctness of the criteria of the recommendation of the prescription of the aerobic exercise for elderly people.

\begin{tabular}{|c|c|c|c|}
\hline \multirow[b]{2}{*}{ Independent variable } & \multicolumn{3}{|c|}{ Aerobic exercise - total of hits } \\
\hline & $\begin{array}{l}\text { All hits } \\
\mathrm{N}(\%)\end{array}$ & $\begin{array}{c}\text { OR }(95 \% \mathrm{Cl}) \\
\text { Crude }\end{array}$ & \begin{tabular}{|l} 
OR $(95 \% \mathrm{Cl})$ \\
Adjusted $\mp$ \\
\end{tabular} \\
\hline Sex & NS & & \\
\hline Male & $28(49,2)$ & 1.00 & 1.00 \\
\hline Female & $29(50,8)$ & $1.13(0.57-3.11)$ & $1.06(0.51-2.99)$ \\
\hline Age range, years & * & & \\
\hline $22-29$ & $16(28,1)$ & 1.00 & 1.00 \\
\hline $30-39$ & $10(17,5)$ & $0.77(0.19-3.05)$ & $0.72(0.22-3.00)$ \\
\hline $40-49$ & $8(14,0)$ & $0.52(0.14-1.89)$ & $0.48(0.15-1.78)$ \\
\hline$\geq 50$ & $23(40,4)$ & $3.07(1.03-9.21)^{*}$ & $3.00(1.01-8.78)^{*}$ \\
\hline $\begin{array}{c}\text { Time of completion of } \\
\text { graduate coursework, years }\end{array}$ & NS & & \\
\hline$\leq 1$ & $6(10,5)$ & 1.00 & 1.00 \\
\hline $1-3$ & $23(40,6)$ & $2.44(0.51-11.65)$ & $2.40(0.55-11.09)$ \\
\hline $4-6$ & $18(31,0)$ & $1.03(0.22-4.80)$ & $1.01(0.24-4.54)$ \\
\hline$\geq 7$ & $10(17,9)$ & $1.04(0.19-5.63)$ & $1.02(0.23-5.11)$ \\
\hline Completed graduate coursework & NS & & \\
\hline $\begin{array}{c}\text { Yes } \\
\end{array}$ & $27(47,4)$ & $0.87(0.50-1.50)$ & $0.89(0.54-1.67)$ \\
\hline No & $30(52,6)$ & 1.00 & 1.00 \\
\hline $\begin{array}{c}\text { Time of end of postgraduate } \\
\text { coursework, years }\end{array}$ & NS & & \\
\hline$\leq 1$ & $3(10,0)$ & 1.00 & 1.00 \\
\hline $1-2$ & $14(46,7)$ & $1.02(0.24-4.44)$ & $1.04(0.25-4.36)$ \\
\hline $3-5$ & $10(33,3)$ & $1.12(0.24-5.28)$ & $1.18(0.28-5.17)$ \\
\hline$\geq 6$ & $3(10,0)$ & $0.95(0.15-6.01)$ & $0.99(0.18-5.78)$ \\
\hline Gym size & NS & & \\
\hline Small ( $\leq 499$ students) & $24(42,1)$ & $1.33(0.68-2.60)$ & $1.28(0.64-2.53)$ \\
\hline Average (500-999 students) & $20(35,1)$ & $1.05(0.55-2.01)$ & $1.02(0.50-1.95)$ \\
\hline Large ( $\geq 1000$ students) & $13(22,8)$ & 1.00 & 1.00 \\
\hline Number of jobs & * & & \\
\hline 1 & $37(64,9)$ & $4.78(1.22-7.68)^{*}$ & $4.70(1.20-7.34)^{*}$ \\
\hline 2 & $14(24,6)$ & $3.89(1.02-2.75)$ & $3.84(1.04-2.09)$ \\
\hline 3 & $6(10,5)$ & 1.00 & 1.00 \\
\hline Hours of weekly reading & NS & & \\
\hline$\leq 1$ & $24(42,1)$ & 1.00 & 1.00 \\
\hline $1-2$ & $20(35,1)$ & $0.20(0.18-1.52)$ & $0.18(0.15-1.50)$ \\
\hline$\geq 3$ & $13(22,8)$ & $0.97(0.33-2.85)$ & $0.97(0.31-2.82)$ \\
\hline Type of reading & * & & \\
\hline Books and scientific articles & $12(21,0)$ & 1.00 & 1.00 \\
\hline Only scientific articles & $29(50,9)$ & $2.32(1.14-5.66)^{*}$ & $2.30(1.11-5.61)^{*}$ \\
\hline Sites and non-scientific texts & $16(28,1)$ & $1.06(0.23-5.67)$ & $1.04(0.21-5.62)$ \\
\hline Total & $57(100,0)$ & & \\
\hline
\end{tabular}

$\mathrm{OR}$, odds ratio; $\mathrm{Cl}$, confidence interval; $\mathrm{NS}$, not significant; ${ }^{*} \mathrm{p}<0.05 ;{ }^{* *} \mathrm{p}<0.001 ;$ F multivariate regression mode adjusted for all other variables in the model.

of these professionals, which could lead to erroneous recommendations for exercise prescriptions in elderly individuals attending gyms. On the other hand, we found studies that evaluated the knowledge of active physical education professionals in gyms regarding the aspects related to exercise prescription and specificities of chronic disease in adults with diabetes ${ }^{9-10}$ and hypertension ${ }^{11}$. In a study by Monteiro et al $(2010)^{11}$, the authors concluded that the knowledge of professionals regarding issues that involve hypertension is insufficient. Goebel et al (2013) ${ }^{22}$ concluded that the knowledge of physical education professionals is insufficient for exercise prescriptions for diabetic individuals. Teixeira et al (2011) found that $70 \%$ of professionals did not know the recommendation of exercise prescription for diabetics. Monteiro et al $(2009)^{9}$ concluded that the knowledge of physical education professionals was insufficient for working with diabetic patients.

In general, the greater knowledge of any phenomenon is associated with schooling ${ }^{23}$. Professionals who finished their postgraduate studies accumulated more years of schooling than those who did not complete postgraduate coursework. Thus, postgraduate professionals tend to have greater knowledge about a particular phenomenon than those with only undergraduate degrees. Data from the present study demonstrate 
Table 4. Description of the knowledge of physical education professionals by independent variable given the criteria of the recommendation of the prescription of exercise with weights for elderly people.

\begin{tabular}{|c|c|c|c|c|}
\hline Independent variable & \begin{tabular}{|c|} 
Weekly \\
frequency, \\
$\mathrm{N}(\%)$
\end{tabular} & \begin{tabular}{|c|} 
No. of \\
exercises, \\
$\mathrm{N}(\%)$
\end{tabular} & $\begin{array}{l}\text { No. of } \\
\text { series, } \\
\text { N (\%) }\end{array}$ & $\begin{array}{c}\text { No. } \\
\text { Repetitions } \\
\text { N (\%) }\end{array}$ \\
\hline Sex & NS & NS & NS & NS \\
\hline Male & $124(44,9)$ & $77(48,1)$ & $67(45,9)$ & $118(46,3)$ \\
\hline Female & $152(55,1)$ & $83(51,9)$ & $79(54,1)$ & $137(53,7)$ \\
\hline Age range, years & * & NS & * & NS \\
\hline $22-29$ & $76(27,5)$ & $54(33,8)$ & $54(37,0)$ & $81(31,8)$ \\
\hline $30-39$ & $49(17,8)$ & $33(20,6)$ & $19(13,0)$ & $48(18,8)$ \\
\hline $40-49$ & $88(31,9)$ & $38(23,8)$ & $42(28,8)$ & $76(29,8)$ \\
\hline$\geq 50$ & $63(22,8)$ & $35(21,9)$ & $31(21,2)$ & $50(19,6)$ \\
\hline $\begin{array}{c}\text { Time of completion of } \\
\text { graduate coursework, years }\end{array}$ & NS & * & NS & NS \\
\hline$\leq 1$ & $44(15,9)$ & $31(19,4)$ & $21(14,4)$ & $33(12,9)$ \\
\hline $1-3$ & $90(32,6)$ & $49(30,6)$ & $47(32,2)$ & $77(30,2)$ \\
\hline $4-6$ & $91(33,0)$ & $60(37,5)$ & $57(39,0)$ & $98(38,4)$ \\
\hline$\geq 7$ & $51(18,5)$ & $20(12,5)$ & $21(14,4)$ & $47(18,4)$ \\
\hline $\begin{array}{c}\text { Completed graduate } \\
\text { coursework }\end{array}$ & 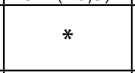 & 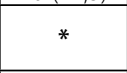 & 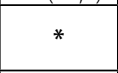 & NS \\
\hline Yes & $158(57,2)$ & $95(59,4)$ & $93(63,7)$ & $146(57,3)$ \\
\hline $\mathrm{No}$ & $118(42,8)$ & $65(40,6)$ & $53(36,3)$ & $109(42,7)$ \\
\hline $\begin{array}{c}\text { Time of end of postgraduate } \\
\text { coursework, years }\end{array}$ & NS & * & * & * \\
\hline$\leq 1$ & $22(13,9)$ & $10(10,5)$ & $15(16,1)$ & $24(16,4)$ \\
\hline $1-2$ & $65(41,1)$ & $34(35,8)$ & $31(33,3)$ & $54(37,0)$ \\
\hline $3-5$ & $49(31,0)$ & $36(37,9)$ & $30(32,2)$ & $45(30,8)$ \\
\hline$\geq 6$ & $22(13,9)$ & $15(15,8)$ & $17(18,3)$ & $23(15,8)$ \\
\hline Gym size & $* *$ & $*$ & $*$ & $* *$ \\
\hline Small ( $\leq 499$ students) & $52(18,8)$ & $38(23,8)$ & $23(15,8)$ & $43(16,9)$ \\
\hline Average (500-999 students) & $71(25,7)$ & $49(30,6)$ & $53(36,3)$ & $68(26,7)$ \\
\hline Large ( $\geq 1000$ students) & $153(55,4)$ & $73(45,6)$ & $70(47,9)$ & $144(56,5)$ \\
\hline Number of jobs & $* *$ & NS & NS & $* *$ \\
\hline 1 & $165(59,8)$ & $90(56,3)$ & $88(60,3)$ & $164(64,3)$ \\
\hline 2 & $84(30,4)$ & $45(28,1)$ & $45(30,8)$ & $69(27,1)$ \\
\hline 3 & $27(9,8)$ & $25(15,6)$ & $13(8,9)$ & $22(8,6)$ \\
\hline Hours of weekly reading & NS & NS & NS & NS \\
\hline$\leq 1$ & $91(33,0)$ & $47(29,4)$ & $49(33,6)$ & $91(35,7)$ \\
\hline $1-2$ & $113(40,9)$ & $76(47,5)$ & $60(41,1)$ & $107(42,0)$ \\
\hline$\geq 3$ & $72(26,1)$ & $37(23,1)$ & $37(25,3)$ & $57(22,4)$ \\
\hline Type of reading & $* *$ & $* *$ & * & NS \\
\hline Books and scientific articles & $76(27,5)$ & $41(25,6)$ & $55(37,7)$ & $80(31,4)$ \\
\hline Only scientific articles & $111(40,2)$ & $67(41,9)$ & $66(45,2)$ & $108(42,4)$ \\
\hline Sites and non-scientific texts & $89(32,2)$ & $52(32,5)$ & $25(17,1)$ & $67(26,3)$ \\
\hline Total & $276(100,0)$ & $160(100,0)$ & $146(100,0)$ & $255(100,0)$ \\
\hline
\end{tabular}

this relationship. Regarding the recommendation of aerobic exercise for elderly people in isolation, professionals with a completed lato sensu postgraduate degree presented a significantly higher percentage of knowledge of the prescription than those who did not complete postgraduate coursework. The same trend was observed regarding knowledge of the recommendation of resistance exercise.

These results demonstrate the importance of postgraduate studies, as these phenomena are discussed in more depth in the various courses offered in the area of physical education, which allows professionals to acquire specific knowledge such as the recommendations of aerobic and resistance exercise for the elderly and the care to be observed during the performance of an exercise program for this group $3,4,14,16,20$.

Working in only one gym was a factor associated with more knowledge, both for each criterion of the recommendations alone and the correctness of all criteria. Professionals who work in only one gym would probably have more time available throughout the day to perform other activities, including searching databases and reading scientific articles. Considering the knowledge of all the criteria that compose the recommendations, professionals who reported reading scientific articles presented an OR of $2.30(95 \% \mathrm{Cl}, 1.11-5.61 ; \mathrm{p}<0.05)$ in the adjusted regression model. This phenomenon can be explained by the higher number of explanatory texts about the recommendations present in a greater number in scientific articles or official guidelines. Several scientific articles of national ${ }^{24}$ and
Table 5. Regression model of the knowledge of the physical education professionals by independent variable given all hits of the criteria of the recommendation of the prescription of exercise with weights for the elderly.

\begin{tabular}{|c|c|c|c|}
\hline \multirow[b]{2}{*}{ Independent variable } & \multicolumn{3}{|c|}{ Exercise with weights total of hits } \\
\hline & $\begin{array}{l}\text { All hits, } \\
\text { N (\%) }\end{array}$ & $\begin{array}{c}\text { OR }(95 \% \mathrm{CI}), \\
\text { crude }\end{array}$ & $\begin{array}{l}\text { OR }(95 \% \mathrm{Cl}), \\
\text { adjusted } \mp\end{array}$ \\
\hline Sex & NS & & \\
\hline Male & $38(49,4)$ & 1.00 & 1.00 \\
\hline Female & $39(50,6)$ & $0.80(0.49-1.29)$ & $0.82(0.50-1.28)$ \\
\hline Age range, years & NS & & \\
\hline $22-29$ & $25(32,5)$ & $1.20(0.60-2.41)$ & $1.18(0.58-2.40)$ \\
\hline $30-39$ & $12(15,6)$ & $0.82(0.36-1.85)$ & $0.81(0.35-1.83)$ \\
\hline $40-49$ & $26(33,8)$ & $1.37(0.68-2.74)$ & $1.35(0.63-2.71)$ \\
\hline$\geq 50$ & $14(18,2)$ & 1.00 & 1.00 \\
\hline $\begin{array}{c}\text { Time of completion of } \\
\text { graduate coursework, years }\end{array}$ & * & & \\
\hline$\leq 1$ & $16(20,8)$ & 1.00 & 1.00 \\
\hline $1-3$ & $34(44,2)$ & $1.87(1.01-3.24)^{*}$ & $1.84(1.02-3.27)^{*}$ \\
\hline $4-6$ & $26(33,8)$ & $1.42(0.87-2.98)$ & $1.40(0.89-3.03)$ \\
\hline$\geq 7$ & $1(1,3)$ & $0.04(0.01-0.32)$ & $0.03(0.01-0.33)$ \\
\hline Completed graduate coursework & * & & \\
\hline Yes & $46(59,7)$ & $1.31(1.02-2.23)$ & $1.25(1.01-1.12)$ \\
\hline No & $31(40,3)$ & 1.00 & 1.00 \\
\hline $\begin{array}{c}\text { Time of end of postgraduate } \\
\text { coursework, years }\end{array}$ & * & & \\
\hline$\leq 1$ & $2(4,3)$ & 1.00 & 1.00 \\
\hline $1-2$ & $21(45,7)$ & $3.68(0.83-16.38)$ & $3.70(0.82-16.37)$ \\
\hline $3-5$ & $21(45,7)$ & $3.68(0.83-16.38)$ & $3.69(0.84-16.36)$ \\
\hline$\geq 6$ & $3(4,3)$ & $1.10(0.14-8.26)$ & $1.10(0.14-8.26)$ \\
\hline Gym size & NS & & \\
\hline Small ( $\leq 499$ students) & $14(18,2)$ & 1.00 & 1.00 \\
\hline Average (500-999 students) & $31(40,3)$ & $1.71(0.88-3.35)$ & $1.74(0.89-3.38)$ \\
\hline Large ( $\geq 1000$ students) & $32(41,6)$ & $1.26(0.65-2.45)$ & $1.27(0.66-2.47)$ \\
\hline Number of jobs & NS & & \\
\hline 1 & $45(58,4)$ & $1.16(0.54-2.47)$ & $1.20(0.56-2.49)$ \\
\hline 2 & $23(29,9)$ & $1.29(0.57-2.92)$ & $1.32(0.58-2.97)$ \\
\hline 3 & $9(11,7)$ & 1.00 & 1.00 \\
\hline Hours of weekly reading & NS & & \\
\hline$\leq 1$ & $23(29,9)$ & 1.00 & 1.00 \\
\hline $1-2$ & $32(41,6)$ & $1.36(0.78-2.40)$ & $1.40(0.79-2.43)$ \\
\hline$\geq 3$ & $22(28,6)$ & $1.02(0.45-2.62)$ & $1.05(0.47-2.66)$ \\
\hline Type of reading & * & & \\
\hline Books and scientific articles & $25(32,5)$ & $2.21(1.03-4.77)^{*}$ & $2.23(1.04-4.75)^{*}$ \\
\hline Only scientific articles & $42(54,5)$ & $2.85(1.39-5.86)^{*}$ & $2.87(1.41-5.87)^{*}$ \\
\hline Sites and non-scientific texts & $10(13,0)$ & \begin{tabular}{|c|}
1.00 \\
\end{tabular} & 1.00 \\
\hline TOTAL & $77(100,0)$ & & \\
\hline
\end{tabular}

NS, not significant; ${ }^{*} \mathrm{p}<0.05 ;{ }^{* *} \mathrm{p}<0.001 ;$ m multivariate regression model adjusted for all other variables in the model.

international $\left.\right|^{3,4,6,25}$ studies have been published on the recommendation of the prescription of aerobic exercise for the elderly.

Based on the results of this study, we conclude that: A) the knowledge of physical education professionals working in São Paulo gyms on the recommendation of aerobic and resistance exercise for elderly people was low in that only $9.3 \%$ and $12.3 \%$ of professionals are familiar with the recommendation of the American College of Sports Medicine considering all criteria for the recommendation of aerobic exercise and resistance, respectively; B) Greater knowledge was associated with postgraduate studies of physical education professionals and the reading of scientific articles, which reinforces the importance of expertise for this group; C) It suggests the need for professional training courses to remedy this gap for already trained professionals; and D) The possibility of including a discipline that mainly focuses on the importance of the practice of exercise by elderly people in undergraduate physical education courses should be discussed.

\section{ACKNOWLEDGMENTS}

The authors thank the Coordination for the Improvement of Higher Education Personnel (Coordenação de Aperfeiçoamento de Pessoal de Nível Superior - CAPES) for its support.

All authors declare no potential conflict of interest related to this article. 
AUTHORS' CONTRIBUTIONS: Each author made significant individual contributions to this manuscript. FC (0000-0001-7829-1184)* data collection, writing of the article and statistical analysis; AFJ (0000-0002-6635-8019)* data collection, writing of the article and statistical analysis; ELA (0000-0002-2598-4558)*: data collection, writing of the article and statistical analysis; TLA (0000-0002-6114-3916)* writing and review of the article, assistance in the statistical analysis; RLR (0000-0002-6145-1337)* writing and review of the article, assistance in the statistical analysis; MLJM (0000-0003-1438-8205)* writing and review of the article, assistance in the statistical analysis; VKRM $(000-0003-3552-486 X)^{*}$ review of results and writing of the article; DSB (0000-0003-3993-8277)* review of results and writing of the article. *ORCID (Open Researcher and Contributor ID).

\section{REFERENCES}

1. World Health Organization. Diet and Physical Activity Factsheet. Secondary Diet and Physical Activity Factsheet. 2013.http://www.who.int/dietphysicalactivity/factsheet_inactivity/en/index.html.

2. Blair S, Sallis R, Hutber A, Archer E. Exercise therapy—-the public health message. Scand J Med Sci Sports. 2012;22(4):e24-8.

3. Chodzko-Zajko WJ, Proctor D, Fiatarone Singh M, Minson CT, Nigg CR, Salem GJ, et al. American College of Sports Medicine position stand. Exercise and physical activity for older adults. Med Sci Sports Exerc. 2009;41(7):1510-30

4. Paterson DH, Jones GR, Rice CL. Ageing and physical activity: evidence to develop exercise recommendations for older adults. Can J Public Health. 2007;98(Suppl 2):S69-108.

5. Sakuma K, Yamaguchi A. Sarcopenia and age-related endocrine function. Int J Endocrinol. 2012;2012:127362

6. World Health Organization. Global recommendations on physical activity for health. Geneva: World Health Organization, 2010.

7. Taylor D. Physical activity is medicine for older adults. Postgrad Med J. 2014;90(1059):26-32.

8. Conselho Federal de Educação Física. Resolução CONFEF no 046/2002. Disponível em: http://www. confef.org.br/extra/resolucoes/conteudo.asp?cd_resol=82. Acesso em: 7 janeiro 2014.

9. Monteiro LZ, Spinato IL, Silva CAB, Pinheiro MHNP, Santos ZMSA, Montenegro Júnior RM. Conhecimento do profissional de Educação Física frente à atuação com portadores de diabetes mellitus nas academias de ginástica de Fortaleza, CE. Rev Bras Educ Fís Esporte. 2009;23(2):135-42.

10. Teixeira LEC, Cruz PWS, Soares MMA, Dos Santos LBA, Borges J, Vancea DMM. Grau de conhecimento dos profissionais de Educação Física sobre a prescrição de exercício física para diabéticos. Revista Brasileira de Ciências da Saúde. 2011;9(29): 25-30

11. Monteiro LZ, Spinato IL, Da Silva CAB, Santos ZMSA, Montenergo Júnior RMM. Nível de conhecimento do Profissional de Educação Física frente a alunos com hipertensão arterial nas academias de ginástica. Rev Bras Cineantropom Desempenho Hum. 2010;12(4):262-8.

12. Victora CG, Huttly SR, Fuchs SC, Olinto MT. The role of conceptual frameworks in epidemiological analysis: a hierarchical aprroach. Int J Epidemiol. 1997;26(1):224-7.

13. Ueshima K, Ishikawa-Takata K, Yorifuji T, Suzuki E, Kashima S, Takao S, et al. Physical activity and mortality risk in the Japanese elderly: a cohort study. Am J Prev Med. 2010;38(4):410-8.
14. Oguma Y, Shinoda-Tagawa T. Physical activity decreases cardiovascular disease risk in women: review and meta-analysis. Am J Prev Med. 2004;26(5):407-18.

15. Pinto A, Di Raimondo D, Tuttolomondo A, Buttà C, Milio G, Licata G. Effects of physical exercise on inflammatory markers of atherosclerosis. Curr Pharm Des. 2012;18(28):4326-49.

16. lijima K, limuro S, Shinozaki T, Ohashi Y, Sakurai T, Umegaki H, et al. Lower physical activity is a strong predictor of cardiovascular events in elderly patients with type 2 diabetes mellitus beyond traditional risk factors: the Japanese elderly diabetes intervention trial. Geriatr Gerontol Int. 2012;12(Suppl 1):77-87.

17. Gregg EW, Cauley J, Stone K, Thompson TJ, Bauer DC, Cummings SR, et al. Relationship of changes in physical activity and mortality among older women. JAMA. 2003;289(18):2379-86.

18. Caspersen CJ, Powell KE, Christenson GM. Physical activity, exercise, and physical fitness: definitions and distinctions for health-related research. Public Health Rep. 1985;100(2):126-31.

19. Jackson AS, Sui X, Hebert JR, Church TS, Blair SN. Role of lifestyle and aging on the longitudinal change in cardiorespiratory fitness. Arch Intern Med. 2009;169(19):1781-7.

20. Paterson DH, Warburton DE. Physical activity and functional limitations in older adults: a systematic review related to Canada's physical activity guidelines. Int J Behav Nutr Phys Act. 2010;7:38.

21. Csapo L, Alegre M. Effects of resistance training with moderate vs heavy loads on muscle mass and strength in the elderly: A meta-analysis. Scand J Med Sci Sports. 2016;26(9):995-1006.

22. Goebel MC, Borges LJ, Barbosa AR. O conhecimento dos profissionais de Educação Física atuantes em academias de ginástica de Florianópolis em relação às pessoas com Diabetes. Rev Bras Ativ Fis Saúde. 2013;18(3):309-16.

23. Knuth AG, Bielemann RN, Da silva SG, Borges TT, Del Luca GF, Kremer MM, et al. Conhecimento de adultos sobre o papel da atividade física na prevenção e tratamento de diabetes e hipertensão: estudo de base populacional no Sul do Brasil. Cad Saúde Pública. 2009;25(3):513-20.

24. Ceschini FL, Figueira Júnior A, Falconi CA, Farias US, AlmeidaVT, Serafim CL, et al. Atividade física e saúde: importância dos Statements para a prática de atividade física em crianças e adolescentes, adultos e idosos. Revista Brasileira de Ciência da Saúde. 2009;7(21):6-9

25. Mendes RNS, Barata JLT. Actividade física e saúde pública: recomendações para a prescrição do exercício Acta Med Port. 2011;24:1025-30 